Kui-Kui Chen, Jing-Tao Huang, Long Lin* and Wei-Na Wu

\title{
Crystal structure of bis( $N^{\prime}$-((5-(ethoxycarbonyl)-1H-pyrrol-2-yl) methylene)- $\mathrm{N}$-ethylcarbamohydrazonothioato- $\left.\mathrm{K}^{2} \mathrm{~N}, 0\right)$ nickel(II), $\mathrm{C}_{22} \mathrm{H}_{30} \mathrm{~N}_{8} \mathrm{O}_{4} \mathrm{~S}_{2} \mathrm{Ni}$
}

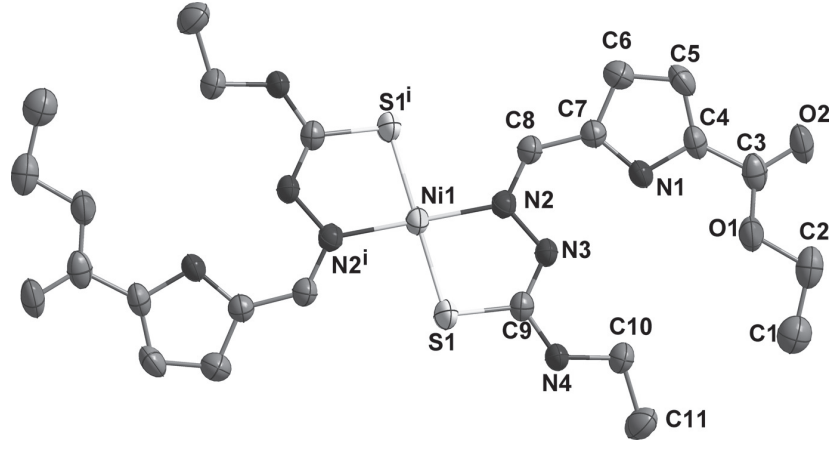

https://doi.org/10.1515/ncrs-2019-0690

Received September 12, 2019; accepted December 5, 2019; available online December 31, 2019

\section{Abstract}

$\mathrm{C}_{22} \mathrm{H}_{30} \mathrm{~N}_{8} \mathrm{O}_{4} \mathrm{~S}_{2} \mathrm{Ni}$, monoclinic, $P 2_{1} / c$ (no. 14), $a=10.635(2) \AA$, $b=10.308(2) \AA, \quad c=12.444(3) \AA, \quad \beta=101.205(4)^{\circ}$, $V=1338.2(5) \AA^{3}, Z=2, R_{\mathrm{gt}}(F)=0.0417, w R_{\mathrm{ref}}\left(F^{2}\right)=0.0937$, $T=296(2) \mathrm{K}$.

\section{CCDC no.: 1970194}

The molecular structure is shown in the figure (hydrogen atoms are omitted for clarity.). Table 1 contains crystallographic data and Table 2 contains the list of the atoms including atomic coordinates and displacement parameters.

\section{Source of material}

The title complex was synthesized by the reaction of $N^{\prime}$-((Z)-(5- (ethoxycarbonyl)-1H -pyrrol-2-yl)methylene)- $N$ ethylcarbamohydrazonothioic acid $(T S C H)(5 \mathrm{mmol})$ with an equimolar amount of $\mathrm{Ni}(\mathrm{OAc})_{2} \cdot 6 \mathrm{H}_{2} \mathrm{O}$ in $\mathrm{MeOH} / \mathrm{THF}(20 \mathrm{~mL}$,

*Corresponding author: Long Lin, School of Materials Science and Engineering, Henan Polytechnic University, Jiaozuo 454000, P.R. China, e-mail: linlong@hpu.edu.cn. https://orcid.org/00000003-1645-5600

Kui-Kui Chen: College of Mining, Shanxi Datong University, Datong 037004, P.R. China

Jing-Tao Huang: School of Materials Science and Engineering, Henan Polytechnic University, Jiaozuo 454000, P.R. China Wei-Na Wu: Department of Chemistry and Chemical Engineering, Henan Polytechnic University, Jiaozuo 454000, P.R. China. https://orcid.org/0000-0002-0874-0703
Table 1: Data collection and handling.

\begin{tabular}{ll}
\hline Crystal: & Black block \\
Size: & $0.18 \times 0.15 \times 0.14 \mathrm{~mm}$ \\
Wavelength: & Mo $K \alpha$ radiation $(0.71073 \AA)$ \\
$\mu:$ & $0.93 \mathrm{~mm}^{-1}$ \\
Diffractometer, scan mode: & Bruker APEX-II, $\varphi$ and $\omega$ \\
$\theta_{\max }$, completeness: & $25.0^{\circ},>99 \%$ \\
$N(h k l)_{\text {measured }}, N(h k l)_{\text {unique }}, R_{\text {int }}:$ & $6691,2353,0.045$ \\
Criterion for $I_{\text {obs }}, N(h k l)_{\text {gt }}:$ & $I_{\text {obs }}>2 \sigma\left(I_{\text {obs }}\right), 1692$ \\
$N(\text { param })_{\text {refined }}:$ & 171 \\
Programs: & SHELX [1], Bruker [2] \\
\hline
\end{tabular}

Table 2: Fractional atomic coordinates and isotropic or equivalent isotropic displacement parameters $\left(\AA^{2}\right)$.

\begin{tabular}{|c|c|c|c|c|}
\hline Atom & $x$ & $y$ & $z$ & $\boldsymbol{U}_{\text {iso }}{ }^{\star} / \boldsymbol{U}_{\text {eq }}$ \\
\hline S1 & $0.44432(8)$ & $0.68589(9)$ & $0.42404(8)$ & $0.0493(3)$ \\
\hline $\mathrm{Ni1}$ & 0.5000 & 0.5000 & 0.5000 & $0.03433(19)$ \\
\hline 01 & $-0.1130(2)$ & $0.6728(2)$ & $0.6376(2)$ & $0.0515(6)$ \\
\hline 02 & $-0.1857(2)$ & $0.5482(2)$ & $0.7619(2)$ & $0.0557(7)$ \\
\hline N1 & $0.1064(2)$ & $0.5305(2)$ & $0.6593(2)$ & $0.0381(7)$ \\
\hline $\mathrm{H} 1$ & 0.0966 & 0.5843 & 0.6055 & $0.046^{*}$ \\
\hline N2 & $0.3471(2)$ & $0.5143(2)$ & $0.5600(2)$ & $0.0346(6)$ \\
\hline N3 & $0.2515(2)$ & $0.6034(2)$ & $0.5176(2)$ & $0.0368(6)$ \\
\hline N4 & $0.2110(2)$ & $0.7809(3)$ & $0.4063(2)$ & $0.0450(7)$ \\
\hline $\mathrm{H} 4$ & 0.2388 & 0.8351 & 0.3638 & $0.054^{*}$ \\
\hline $\mathrm{C} 1$ & $-0.2329(4)$ & $0.8346(4)$ & $0.5256(3)$ & $0.0655(11)$ \\
\hline $\mathrm{H} 1 \mathrm{~A}$ & -0.2354 & 0.7818 & 0.4616 & $0.098^{*}$ \\
\hline $\mathrm{H} 1 \mathrm{~B}$ & -0.1573 & 0.8876 & 0.5370 & $0.098^{*}$ \\
\hline $\mathrm{H} 1 \mathrm{C}$ & -0.3075 & 0.8890 & 0.5155 & $0.098^{\star}$ \\
\hline $\mathrm{C} 2$ & $-0.2305(3)$ & $0.7496(4)$ & $0.6227(3)$ & $0.0582(10)$ \\
\hline $\mathrm{H} 2 \mathrm{~A}$ & -0.2318 & 0.8018 & 0.6873 & 0.070 * \\
\hline $\mathrm{H} 2 \mathrm{~B}$ & -0.3048 & 0.6930 & 0.6109 & $0.070^{\star}$ \\
\hline C3 & $-0.1030(3)$ & $0.5770(3)$ & $0.7113(3)$ & $0.0458(9)$ \\
\hline $\mathrm{C} 4$ & $0.0195(3)$ & $0.5101(3)$ & $0.7256(3)$ & $0.0419(8)$ \\
\hline C5 & $0.0703(3)$ & $0.4174(3)$ & $0.8012(3)$ & $0.0518(10)$ \\
\hline H5 & 0.0320 & 0.3845 & 0.8566 & $0.062^{*}$ \\
\hline $\mathrm{C} 6$ & $0.1887(3)$ & $0.3820(3)$ & $0.7801(3)$ & $0.0486(9)$ \\
\hline H6 & 0.2440 & 0.3210 & 0.8190 & $0.058^{\star}$ \\
\hline $\mathrm{C} 7$ & $0.2104(3)$ & $0.4529(3)$ & $0.6911(3)$ & $0.0376(8)$ \\
\hline $\mathrm{C} 8$ & $0.3206(3)$ & $0.4472(3)$ & $0.6414(3)$ & $0.0370(8)$ \\
\hline $\mathrm{H} 8$ & 0.3823 & 0.3866 & 0.6715 & $0.044^{*}$ \\
\hline C9 & $0.2907(3)$ & $0.6877(3)$ & $0.4521(3)$ & $0.0355(8)$ \\
\hline C10 & $0.0806(3)$ & $0.7973(3)$ & $0.4230(3)$ & $0.0455(9)$ \\
\hline $\mathrm{H} 10 \mathrm{~A}$ & 0.0817 & 0.8328 & 0.4954 & $0.055^{\star}$ \\
\hline
\end{tabular}

ə Open Access. ( 2019 Kui-Kui Chen et al., published by De Gruyter. (c) BY This work is licensed under the Creative Commons Attribution 4.0 Public License. 
Table 2 (continued)

\begin{tabular}{lrrrr}
\hline Atom & $\boldsymbol{x}$ & $\boldsymbol{y}$ & $\boldsymbol{z}$ & $\boldsymbol{U}_{\text {iso }}{ }^{*} / \boldsymbol{U}_{\text {eq }}$ \\
\hline H10B & 0.0378 & 0.7138 & 0.4183 & $0.055^{*}$ \\
C11 & $0.0085(3)$ & $0.8879(4)$ & $0.3370(3)$ & $0.0617(11)$ \\
H11A & 0.0021 & 0.8494 & 0.2658 & $0.093^{*}$ \\
H11B & 0.0536 & 0.9688 & 0.3393 & $0.093^{*}$ \\
H11C & -0.0759 & 0.9029 & 0.3511 & $0.093^{*}$ \\
\hline
\end{tabular}

$v: v=1: 1)$. The reaction mixture was filtered and set aside to crystallize for several days, giving black block crystals.

\section{Experimental details}

The structure was solved by direct methods and refined with the SHELX crystallographic software package [1]. The hydrogen atoms were placed at calculated positions and refined as riding atoms with isotropic displacement parameters.

\section{Comment}

Thiosemicarbazones (TSCs) and their transition metal complexes have attracted attention in the coordination chemistry because of their high biological and pharmaceutical activities, such as antibacterial, antiviral, antifungal, antitumor activity and so on [3, 4]. It is noted that $N(4)$-substituted TSCs bearing pyrrole units could act as potential chemotherapeutic agents [5, 6]. Herein, the title Ni(II) complex with a pyrrole-TSC ligand is reported, which was synthesized and characterized by X-ray diffraction.

In the title structure, the asymmetric unit contains one half of the complex with Ni1 atom lying on the inversion center [the figure, symmetry code: (i) $-x+1,-y+1,-z+1$ ]. The four-coordinated Ni(II) ion is in a distorted square planar geometry with the donor sets of two $\mathrm{N}$ and two $\mathrm{S}$ atoms from two dependent TSC ligands. The length of $\mathrm{C}-\mathrm{S}$ is 1.736(3) $\AA$, which is much longer than that of 1.691(19) $\AA$ in the free molecule [6], showing that the TSC ligand has thiolated and deprotonated. Furthermore, the imine $\mathrm{C}=\mathrm{N}(\mathrm{C} 8-\mathrm{N} 2)$ bond adopted a $Z$ configuration instead of $E$ in the free molecule [6]. In the solid state, intermolecular $\mathrm{N}-\mathrm{H} \cdots \mathrm{O}$ hydrogen bonds between the terminal amino $\mathrm{N}$ and carboxylate $\mathrm{O}$ atoms link molecules into a two-dimensional supermolecular network. In addition, the intramolecular $\mathrm{N}-\mathrm{H} \cdots \mathrm{N}$ hydrogen bond between the pyrrole $\mathrm{N}$ and the imine $\mathrm{N}(\mathrm{N} 3)$ atom is present (see the Figure). All egmetic parameters are similar to those derived for the parent structure [7] and related ones [8].

\section{References}

1. Sheldrick, G. M.: Crystal refinement with SHELX. Acta Crystallogr. C71 (2015) 3-8.

2. Bruker. SMART and SAINT. Bruker AXS Inc., Madison, WI, USA (2007).

3. Palanimuthu, D.; Shinde, S. V.; Somasundaram, K.; Samuelson, A. G.: In vitro and in vivo anticancer activity of copper bis(thiosemicarbazone) complexes. J. Med. Chem. 56 (2013) 722-734.

4. Matesanz, A. I.; Leitao, I.; Souza, P.: Palladium(II) and platinum(II) bis(thiosemicarbazone) complexes of the 2,6diacetylpyridine series with high cytotoxic activity in cisplatin resistant A2780cisR tumor cells and reduced toxicity. J. Inorg. Biochem. 125 (2013) 26-31.

5. Li, X.-J.; Mao, P.-D.; Wu, W.-N.; Kou, K.; Liu, S.-Y.; Wang, Y.: $\mathrm{Ni}(\mathrm{II}) / \mathrm{Cu}(\mathrm{II})$ complexes with two pyrrole thiosemicarbazone ligands: Crystal structures and DNA interaction. Chin. J. Inorg. Chem. 33 (2017) 1257-1265.

6. Zhu, T.-F.; Shen, S.-S.; Lu, Q.; Ye, X.-P.; Ding, W.-L.; Chen, R.-H.; Xie, J.; Zhu, W.-J.; Xu, J.; Jia, L.; Wu, W.-N.; Ma, T.-L.: Design and synthesis of novel N(4)-substituted thiosemicarbazones bearing a pyrrole unit as potential anticancer agents. Oncol. Lett. 13 (2017) 4493-4500.

7. Bermejo, E.; Castineiras, A.; Perez, T.; Carballo, R.; Hiller, W.: Synthesis and structural characterization of metal complexes of 2-formylpyrrole- ${ }^{4} \mathrm{~N}$-ethylthiosemicarbazone $\left(4 \mathrm{EL}_{1}\right)$ and 2acetylpyrrole- ${ }^{4} \mathrm{~N}$-ethylthiosemicarbazone $\left(4 \mathrm{EL}_{2}\right)$. Z. Anorg. Allg. Chem. 627 (2001) 2377-2385.

8. Lobana, T. S.; Kumari, P.; Zeller, M.; Butcher, R. J.: The influence of the substituents at $\mathrm{N}^{1}$ nitrogen on geometry of nickel(II) complexes with heterocyclic thiosemicarbazones. Inorg. Chem. Commun. 11 (2008) 972-974. 